\title{
Further Observations on Genetic Transformation in Pseudomonas
}

\author{
By N. C. KHAN AND S. P. SEN \\ Microbiology Laboratory, Botany Department, Faculty of Science, \\ Kalyani University, Kalyani 74I235, India
}

(Received 26 June 1973; revised 20 February 1974)

\begin{abstract}
S U M M A R Y
Intraspecific transformation in three strains of Pseudomonas fluorescens was observed with respect to gelatin liquefaction and chlortetracycline resistance. In interspecific transformation experiments involving 23 pairs of strains and four markers, two yielded positive results: a strain of $P$. fluorescens acquired the property of gelatin liquefaction when transformed with $P$. aeruginosa DNA, and a strain of fish Pseudomonas, incapable of growing at $37{ }^{\circ} \mathrm{C}$, did so when transformed with DNA from another strain of $P$. aeruginosa. The guanine-cytosine content of the DNA of the strains investigated ranged between $6 \mathrm{I} \cdot 0$ and $64.4 \mathrm{~mol} \%$. The transforming ability of DNA was destroyed by DNase. The divalent ions $\mathrm{Mg}^{2+}, \mathrm{Ca}^{2+}$ and $\mathrm{Ba}^{2+}$ improved transformation frequency several fold. Actinomycin D inhibited transformation.
\end{abstract}

\section{INTRODUCTION}

In a previous paper (Khan \& Sen, 1967) we have described our observations concerning intra- and interspecific transformation in Pseudomonas. Intraspecific transformation was reported for Pseudomonas aeruginosa with respect to isoleucine and valine requirement. Interspecific transformation of gelatin liquefaction was demonstrated in eight species of Pseudomonas. Pigment production, however, could not be transferred. Transformation frequency was highest towards the end of the exponential phase of growth of the recipient bacteria and a DNA concentration of $10 \mu \mathrm{g} / \mathrm{ml}$ gave the best results. Optimum temperature for transformation was 25 to $30{ }^{\circ} \mathrm{C}$ and agitation and starvation in diluted media improved transformation frequency.

The present studies extend to a larger number of strains and markers and the requirements for transformation are defined. The DNA base composition of most of the strains used was also determined.

\section{METHODS}

Organisms. The strains used, their phenotypes and sources are listed in Table I.

Media. The media used were the same as described by Khan \& Sen (1967). Colwell's YSP medium (yeast extract, $3 \mathrm{~g}$; sodium chloride, $5 \mathrm{~g}$; peptone, $10 \mathrm{~g}$; agar, $20 \mathrm{~g}$; water to

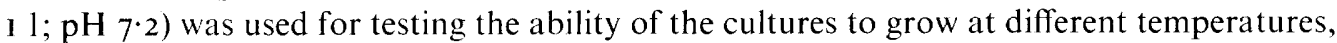
and for the study of egg-yolk reactions and sensitivity to antibiotics. This medium was also used for isolation of large amounts of Pseudomonas.

Genetic markers. The following characters were used as markers: gelatin liquefaction, pigment production, capacity to grow at 37 and $42{ }^{\circ} \mathrm{C}$, and chlortetracycline resistance. All the strains of $P$. aeruginosa produced a blue-green diffusible pigment and liquefied gelatin. Of the $P$. fluorescens strains, only NRRL-BIO was capable of gelatin liquefaction. Fish 
Table I. Strains used

Strain

Phenotype

Pseudomonas aeruginosa LCI

P. aeruginosa 78

P. aeruginosa ilvA9

$P$. aeruginosa 215

P. fluorescens Darrell

P. fluorescens ATCCI 2633

Fish Pseudomonas I

Fish Pseudomonas 2I

$P$. fluorescens NRRL-BIO

$P$. denitrificans NRRL-B 775

P. putrefaciens NRRL-B950

P. stutzeri NRRL-B927

P. mangiferaeindicae $\mathrm{P} 24$

P. solanacearum $\mathrm{P} 25$

Bacillus subtilis MB294

Sarcina lutea
Gelatin liquefaction, growth at 37 and $42 \mathrm{C}$, pigment production

Gelatin liquefaction, growth at 37 and $42 \mathrm{C}$, pigment production

Isoleucine and valine require ment

Gelatin liquefaction, growth at 37 and $42 \mathrm{C}$, pigment production

Lacking gelatin-liquefying capacity

Lacking gelatin-liquefying capacity, chlortetracycline resistance Lacking growth at 37 and $42 \mathrm{C}$, capable of liquefying gelatin

Lacking gelatin-liquefying capacity

Gelatin-liquefying capacity

Lacking gelatin-liquefying capacity and incapable of growing at $42 \mathrm{C}$

Lacking gelatin-liquefying capacity and incapable of growing at $42 \mathrm{C}$

Lacking gelatin-liquefying capacity and incapable of growing at $42 \mathrm{C}$

Lacking gelatin-liquefying capacity and incapable of growing at $42 \mathrm{C}$

Lacking gelatin-liquefying capacity and incapable of growing at $42 \mathrm{C}$

Gelatin liquefaction and growth at $37 \mathrm{C}$

Gelatin liquefaction and growth at $37^{\circ} \mathrm{C}$
Source

Laboratory culture, originally obtained from Calcutta Hospital

\}

Dr J. S. Loutit, Dunedin,

New Zealand

Dr J. H. Darrell, London

Dr G. L. Bullock, Leetown, W.

Va, U.S.A.

Dr W. C. Haynes, Peoria, Illinois, U.S.A.

Indian Type Culture Collection, New Delhi, India

Dr H. B. Woodruff, Rahway,

New Jersey, U.S.A.

Dey's Medical Stores (Manufacturing) Pvt. Ltd, Calcutta, India

Pseudomonas 21 and $P$. solanacearum P25 also possessed this property. Only strains of $P$. aeruginosa and $P$. stutzeri could grow at $42{ }^{\circ} \mathrm{C}$. In addition to these strains, $P$. mang $i$ feraeindicae P24 and $P$. solanacearum P25 also grew well at $37^{\circ} \mathrm{C}$. As the strains of $P$. fluorescens varied considerably in their sensitivity towards chlortetracycline, chlortetracycline resistance was used as a marker for intraspecific transformation involving P. fluorescens.

Isolation of transforming $D N A$. The methods of isolation, purification and estimation of DNA were described by Khan \& Sen (1967).

Transformation. The transformation procedure, including the control experiments, was as described by Khan \& Sen (I967). The sterility of the DNA preparation was checked before each experiment. To test for the presence of contaminant spore formers, DL-alanine $(20 \mu \mathrm{g} / \mathrm{ml})$ and glucose $(0.5 \%, \mathrm{w} / \mathrm{v})$ were added to the DNA solutions, which were incubated at $30^{\circ} \mathrm{C}$ for $24 \mathrm{~h}$ to permit germination of spores and then plated out on nutrient agar (Lab 
Lemco, Io g; peptone, $10 \mathrm{~g}$; sodium chloride, $5 \mathrm{~g}$; glucose, I g; agar, $20 \mathrm{~g}$; water to I 1 ; $\mathrm{pH} 7 \cdot 2$ ).

The method of scoring gelatin-liquefying transformants has been described by Khan \& Sen (1967). To isolate antibiotic resistant transformants, dilution plates of the transformation mixture were incubated at $30^{\circ} \mathrm{C}$ for $\mathrm{I} \mathrm{h}$ and then slowly overlayered with $5 \mathrm{ml}$ of nutrient agar containing the antibiotic, followed by incubation at the same temperature. When heat tolerance was the marker, the experimental and control plates were incubated at 37 and $42{ }^{\circ} \mathrm{C}$.

To study the requirement for metal ions for transformation, competent cells were washed twice with $0.05 \mathrm{M}$-tris- $\mathrm{HCl}$ buffer $\left(\mathrm{pH}_{7 \cdot 2}\right.$ ) containing $0.5 \%$ glucose, before incubation with and without the salts dissolved in the same buffer. The salts used were: $\mathrm{NaCl}$, $\mathrm{KCl}, \mathrm{MgSO}_{4}, \mathrm{CaCl}_{2}$ and $\mathrm{BaCl}_{2}$, each at a concentration of $10^{-3} \mathrm{M}$, and $\mathrm{MnCl}_{2}, \mathrm{FeSO}_{4}$, $\mathrm{ZnSO}_{4}$ and $\mathrm{CuSO}_{4}$, each at a concentration of $\mathrm{IO}^{-4} \mathrm{M}$.

The requirement for DNA-dependent RNA synthesis for transformation was studied by incorporating actinomycin D, a well known inhibitor of DNA-dependent RNA synthesis, in the transformation mixture. Fish Pseudomonas $\mathrm{I}$ was the donor and $P$. fluorescens ATCCI 2633 the recipient, with gelatin liquefaction as the marker. The recipient was grown in nutrient broth for $18 \mathrm{~h}$, and $0.45 \mathrm{ml}$ of a suspension containing $2.7 \times 10^{7}$ organisms $/ \mathrm{ml}$ was mixed with $3.6 \mathrm{ml}$ saline, and $0.45 \mathrm{ml}$ fresh nutrient broth was added to it. For pretreatment with actinomycin $\mathrm{D}, \mathrm{I} \mathrm{ml}$ of the cell suspension was treated with the antibiotic at a concentration of $\mathrm{I} O \mu \mathrm{g} / \mathrm{ml}$ (lethal concentration $20 \mu \mathrm{g} / \mathrm{ml}$ ) and incubated for $5 \mathrm{~min}$. The cells were then centrifuged, washed and resuspended in $\mathrm{I} \cdot 0 \mathrm{ml}$ of transformation medium followed by the addition of $\mathrm{I} \cdot 0 \mathrm{ml}$ DNA dissolved in saline ( $\mathrm{I} 0 \mu \mathrm{g} / \mathrm{ml})$. The control tubes included $\mathrm{I} \mathrm{ml}$ cell suspension and $\mathrm{I} \mathrm{ml}$ transforming DNA. The tubes were shaken for $30 \mathrm{~min}$ at $30{ }^{\circ} \mathrm{C}$ in a rotary shaker $(200 \mathrm{rev} . / \mathrm{min})$, treated with DNase ( $\left.10 \mu \mathrm{g} / \mathrm{ml}\right)$ containing $5 \mu \mathrm{mol} \mathrm{MgCl}_{2} / \mathrm{ml}$, and the number of transformants formed was calculated by dilution plating in nutrient agar containing $0.5 \%$ gelatin.

The decay of transforming ability due to DNase treatment. The effect of DNase on the transforming ability of donor DNA was studied using Pseudomonas aeruginosa ilv $A 9$ as the recipient strain. Before transformation the DNA of $P$. aeruginosa 78 was digested with DNase $(10 \mu \mathrm{g} / \mathrm{ml})$ for $0,8,15,60,120,240$ and $300 \mathrm{~s}$ at $37^{\circ} \mathrm{C}$. The DNase was inactivated by the addition of trisodium citrate to a final concentration of $10 \mu \mathrm{mol} / \mathrm{ml}$. Preliminary experiments had revealed that trisodium citrate itself had no inhibitory effect on transformation. The DNase-treated preparation was then applied to the recipient for $10 \mathrm{~min}$. Dilutions of the incubation mixture were plated out in (i) Morihara's (1964) medium alone, (ii) Morihara's medium + valine, and (iii) Morihara's medium + isoleucine, and incubated at $37^{\circ} \mathrm{C}$. Transformation frequency was calculated as described previously.

DNA base composition. DNA base composition was calculated from the thermal denaturation temperature ( $\left.T_{m}\right)$ of DNA following the method of Marmur \& Doty (I962). The thermal denaturation profile was studied with a Hilgers' Spectrophotometer fitted with a temperature control device.

\section{RESULTS}

\section{Intraspecific transformation}

Intraspecific transformation in Pseudomonas fluorescens has been observed with respect to two markers, gelatin liquefaction and chlortetracyline resistance (Table 2). The transformation frequency varied from 0.07 to $0.71 \%$. Pseudomonas fluorescens ATCC 12633 and $P$. fluorescens Darrell were transformed by $P$. fluorescens NRRL-BIO DNA. Pseudomonas 
Table 2. Intraspecific transformation in Pseudomonas

\begin{tabular}{|c|c|c|c|c|c|}
\hline $\begin{array}{l}\text { Recipient } \\
\text { strains }\end{array}$ & $\begin{array}{c}\text { Source of } \\
\text { donor DNA }\end{array}$ & $\begin{array}{l}\text { Phenotype } \\
\text { selected }\end{array}$ & $\begin{array}{c}\mathrm{IO}^{-4} \times \\
\text { trans- } \\
\text { formants/ } \\
\mathrm{ml}\end{array}$ & $\begin{array}{c}\mathrm{IO}^{-6} \times \\
\text { viable } \\
\text { organisms } \\
\mathrm{ml}\end{array}$ & $\begin{array}{c}\text { Trans- } \\
\text { formation } \\
\text { frequency } \\
(\%)\end{array}$ \\
\hline \multirow[t]{5}{*}{$\begin{array}{l}\text { P. fluorescens } \\
\text { ATCC I } 2633\end{array}$} & $\begin{array}{l}\text { P. fluorescens } \\
\text { NRRL-BIO }\end{array}$ & $\begin{array}{l}\text { Gelatin } \\
\text { liquefaction }\end{array}$ & $5 \cdot 0$ & $7 \cdot 0$ & 0.71 \\
\hline & $\begin{array}{l}\text { P. fluorescens } \\
\text { NRRL-BIO } \\
\text { (DNase treated) }\end{array}$ & $\begin{array}{l}\text { Gelatin } \\
\text { liquefaction }\end{array}$ & o & $7 \cdot 0$ & Nil \\
\hline & $\begin{array}{l}\text { P. fluorescens } \\
\text { ATCC } 12633\end{array}$ & $\begin{array}{l}\text { Gelatin } \\
\text { liquefaction }\end{array}$ & 0 & $6 \cdot 8$ & Nil \\
\hline & S. lutea & $\begin{array}{l}\text { Gelatin } \\
\text { liquefaction }\end{array}$ & 0 & $7 \cdot 0$ & Nil \\
\hline & B. subtilis & $\begin{array}{l}\text { Gelatin } \\
\text { liquefaction }\end{array}$ & 0 & $7 \cdot I$ & Nil \\
\hline \multirow[t]{7}{*}{$\begin{array}{l}\text { P. fluorescens } \\
\text { Darrell }\end{array}$} & $\begin{array}{l}\text { P. fluorescens } \\
\text { ATCC1 } 2633\end{array}$ & $\begin{array}{l}\text { Chlorletracyclin } \\
\text { resistance }\end{array}$ & 0.5 & $6 \cdot 4$ & 0.077 \\
\hline & $\begin{array}{l}\text { P. fluorescens } \\
\text { ATCCI2633 } \\
\text { (DNase treated) }\end{array}$ & $\begin{array}{l}\text { Chlortetracyclin } \\
\text { resistance }\end{array}$ & o & $6 \cdot 4$ & Nil \\
\hline & $\begin{array}{l}\text { P. fluorescens } \\
\text { NRRL-BIO }\end{array}$ & $\begin{array}{l}\text { Gelatin } \\
\text { liquefaction }\end{array}$ & I. 25 & $7 \cdot 5$ & 0.16 \\
\hline & $\begin{array}{l}\text { P. fluorescens } \\
\text { NRRL-BIO } \\
\text { (DNase treated) }\end{array}$ & $\begin{array}{l}\text { Gelatin } \\
\text { liquefaction }\end{array}$ & 0 & $7 \cdot 5$ & Nil \\
\hline & $\begin{array}{l}\text { P. fluorescens } \\
\text { Darrell }\end{array}$ & $\begin{array}{l}\text { Gelatin } \\
\text { liquefaction }\end{array}$ & 0 & $7 \cdot 3$ & Nil \\
\hline & S. lutea & $\begin{array}{l}\text { Gelatin } \\
\text { liquefaction }\end{array}$ & 0 & $7 \cdot 0$ & Nil \\
\hline & Bacillus subtilis & $\begin{array}{l}\text { Gelatin } \\
\text { liquefaction }\end{array}$ & 0 & $7 \cdot \mathrm{I}$ & Nil \\
\hline
\end{tabular}

Table 3. Interspecific transformation in Pseudomonas

\begin{tabular}{|c|c|}
\hline $\begin{array}{l}\text { Recipient } \\
\text { strain }\end{array}$ & $\begin{array}{c}\text { Source of } \\
\text { donor DNA }\end{array}$ \\
\hline \multirow{3}{*}{$\begin{array}{l}\text { P. fluorescens } \\
\text { Darrell }\end{array}$} & P. aeruginosa 215 \\
\hline & $\begin{array}{l}\text { P. aeruginosa } 215 \\
\text { (DNase treated) } \\
\text { P. fluorescens } \\
\text { Darrell } \\
\text { P. aeruginosa } \mathrm{LCI} \\
\text { P. aeruginosa } 78\end{array}$ \\
\hline & $\begin{array}{l}\text { P. aeruginosa } 215 \\
\text { P. solanacearum } \\
\text { P25 } \\
\text { P. stutzeri } \\
\text { NRRL-13927 }\end{array}$ \\
\hline $\begin{array}{l}\text { P. fluorescens } \\
\text { ATCCI } 2633\end{array}$ & $\begin{array}{l}\text { P. aeruginosa } \\
\text { LCI } \\
\text { P. aeruginosa } 78\end{array}$ \\
\hline
\end{tabular}

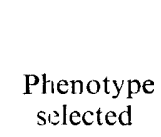

Gelatin

liquefaction

Gelatin

liquefaction

Gelatin

liquefaction

Growth at $37^{\circ} \mathrm{C}$

Gelatin

liquefaction and growth at $37^{\circ} \mathrm{C}$

Growth at $42^{\circ} \mathrm{C}$

Gelatin

liquefaction

Growth at $42^{\circ} \mathrm{C}$

Growth at $37^{\circ} \mathrm{C}$

Gelatin

liquefaction and

growth at $37^{\circ} \mathrm{C}$

\begin{tabular}{|c|c|c|}
\hline $\begin{array}{c}10^{-4} \times \\
\text { trans- } \\
\text { formants/ } \\
\mathrm{ml}\end{array}$ & $\begin{array}{c}10^{-6} \times \\
\text { viable } \\
\text { organisms } / \\
\mathrm{ml}\end{array}$ & $\begin{array}{c}\text { Trans- } \\
\text { formation } \\
\text { frequency } \\
(\%)\end{array}$ \\
\hline 5.0 & $6 \cdot 8$ & 0.7 \\
\hline 0 & $6 \cdot 8$ & Nil \\
\hline 0 & $6 \cdot 8$ & Nil \\
\hline o & $7 \cdot 5$ & Nil \\
\hline 0 & $7 \cdot 5$ & Nil \\
\hline 0 & $6 \cdot 8$ & Nil \\
\hline 0 & $7 \cdot 4$ & Nil \\
\hline 0 & $7 \cdot 4$ & Nil \\
\hline 0 & $7 \cdot 4$ & Nil \\
\hline 0 & $6 \cdot 4$ & Nil \\
\hline 0 & $7 \cdot \mathbf{I}$ & Nil \\
\hline
\end{tabular}


Table 3 (cont.)

\begin{tabular}{|c|c|c|c|c|c|}
\hline $\begin{array}{l}\text { Recipient } \\
\text { strain }\end{array}$ & $\begin{array}{c}\text { Source of } \\
\text { donor DNA }\end{array}$ & $\begin{array}{l}\text { Phenotype } \\
\text { selected }\end{array}$ & $\begin{array}{l}\text { trans- } \\
\text { formants/ } \\
\mathrm{ml}\end{array}$ & $\begin{array}{c}\text { viable } \\
\text { organisms/ } \\
\mathrm{ml}\end{array}$ & $\begin{array}{c}\text { formation } \\
\text { frequency } \\
(0)\end{array}$ \\
\hline \multirow[t]{3}{*}{$\begin{array}{c}\text { P. fluorescens } \\
\text { ATCC } 12633\end{array}$} & P. aeruginosa 215 & $\begin{array}{l}\text { Growth at } 42 \mathrm{C} \\
\text { and pigment } \\
\text { production }\end{array}$ & o & $6 \cdot 4$ & Nil \\
\hline & $\begin{array}{l}\text { P. solanacearum } \\
\text { P25 }\end{array}$ & $\begin{array}{l}\text { Gelatin } \\
\text { liquefaction }\end{array}$ & o & $5 \cdot 8$ & Nil \\
\hline & $\begin{array}{l}P . \text { stutzeri } \\
\text { NRRL-B927 }\end{array}$ & Growth at $42^{\circ} \mathrm{C}$ & o & $7 \cdot 5$ & $\mathrm{Nil}$ \\
\hline $\begin{array}{l}\text { Fish Pseudo- } \\
\text { monas I }\end{array}$ & $P$. aeruginosa 215 & Growth at $42 \mathrm{C}$ & 0 & $7 \cdot 0$ & Nil \\
\hline \multirow{8}{*}{$\begin{array}{l}\text { Fish Pseudo- } \\
\text { monas } 2 \text { I }\end{array}$} & P. aeruginosa 78 & Growth at $37^{\circ} \mathrm{C}$ & $5 \cdot 0$ & $6 \cdot 2$ & 0.8 \\
\hline & $\begin{array}{l}\text { P. aeruginosa } 78 \\
\text { (DNase treated) }\end{array}$ & Growth at $37 \mathrm{C}$ & 0 & $6 \cdot 2$ & Nil \\
\hline & $\begin{array}{l}\text { Fish } \\
\text { Pseudomonas 2I }\end{array}$ & Growth at $37^{\circ} \mathrm{C}$ & 0 & $6 \cdot 4$ & Nil \\
\hline & $P$. aeruginosa $\mathrm{LCI}$ & $\begin{array}{l}\text { Gelatin } \\
\text { liquefaction }\end{array}$ & 0 & $6 \cdot 4$ & Nil \\
\hline & $P$. aeruginosa $2 \mathrm{I} 5$ & $\begin{array}{l}\text { Gelatin } \\
\text { liquefaction, } \\
\text { growth at } 42^{\circ} \mathrm{C} \\
\text { and pigment } \\
\text { production }\end{array}$ & 0 & $6 \cdot 9$ & Nil \\
\hline & Sarcina lutea & Growth at $37^{\circ} \mathrm{C}$ & 0 & $7 \cdot 0$ & Nil \\
\hline & Bacillus subtilis & Growth at $37^{\circ} \mathrm{C}$ & o & $7 \cdot 0$ & Nil \\
\hline & $\begin{array}{l}\text { P. solanacearum } \\
\text { P25 }\end{array}$ & $\begin{array}{l}\text { Gelatin } \\
\text { liquefaction }\end{array}$ & 0 & $7 \cdot 5$ & Nil \\
\hline \multirow{3}{*}{$\begin{array}{l}\text { P. mangi- } \\
\text { feraeindicae } \\
\text { P24 }\end{array}$} & $P$. aeruginosa LCI & $\begin{array}{l}\text { Gelatin } \\
\text { liquefaction }\end{array}$ & o & $8 \cdot 2$ & Nil \\
\hline & P. aeruginosa 215 & $\begin{array}{l}\text { Gelatin } \\
\text { liquefaction }\end{array}$ & 0 & $5 \cdot I$ & Nil \\
\hline & $\begin{array}{l}\text { P. fluorescens } \\
\text { NRRL-BIO }\end{array}$ & $\begin{array}{l}\text { Gelatin } \\
\text { liquefaction }\end{array}$ & 0 & $7 \cdot 0$ & Nil \\
\hline \multirow[t]{2}{*}{$\begin{array}{l}\text { P. denitrificans } \\
\text { NRRL-B775 }\end{array}$} & P. fluorescens 215 & $\begin{array}{l}\text { Gelatin } \\
\text { liquefaction and } \\
\text { growth at } 42 \mathrm{C}\end{array}$ & o & $5 \cdot 2$ & Nil \\
\hline & $\begin{array}{l}\text { P. fluorescens } \\
\text { NRRL-BIO }\end{array}$ & $\begin{array}{l}\text { Gelatin } \\
\text { liquefaction }\end{array}$ & 0 & $6 \cdot I$ & Nil \\
\hline \multirow[t]{2}{*}{$\begin{array}{l}P . \text { putrefaciens } \\
\text { NRRL-BIO }\end{array}$} & $P$. aeruginosa $2 \mathrm{I} 5$ & $\begin{array}{l}\text { Growth at } 42^{\circ} \mathrm{C} \\
\text { and gelatin } \\
\text { liquefaction }\end{array}$ & 0 & $6 \cdot 1$ & Nil \\
\hline & $\begin{array}{l}\text { P. fluorescens } \\
\text { NRRL-B } 10\end{array}$ & $\begin{array}{l}\text { Gelatin } \\
\text { liquefaction }\end{array}$ & 0 & $5 \cdot 7$ & Nil \\
\hline
\end{tabular}

fluorescens Darrell could also be transformed by P. fluorescens ATCCI2633. None of the recipient strains could be transformed when the transforming DNA was degraded by DNase before transformation. No transformation was observed when the recipients were treated with their own DNA or with the DNA of an unrelated organism such as Sarcina lutea or Bacillus subtilis.

\section{Interspecific transformation}

The results of interspecific transformation involving 23 pairs of strains and four markers are given in Table 3. Only two experiments yielded positive results and no transformants 


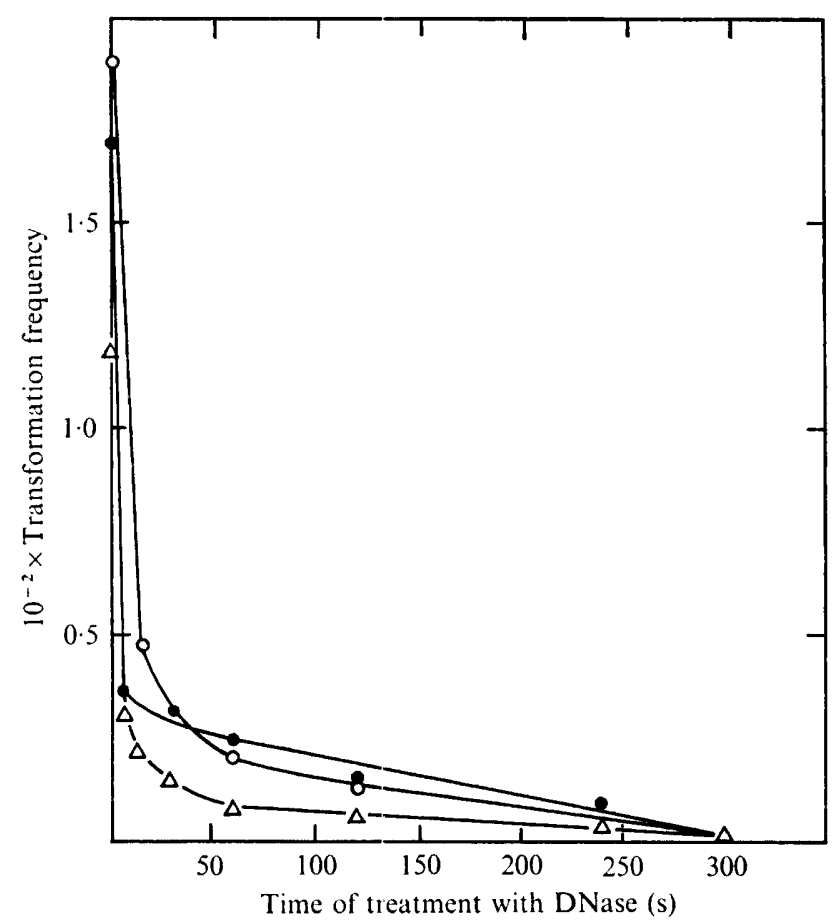

Fig. I. Decay of transforming ability of DNA due to DNase treatment. Formation of transformants when medium was supplemented with only isoleucine $(O)$, only valine $(\odot)$, and no amino acid $(\triangle)$. Donor, $P$. aeruginosa 78 ; recipient, $P$. aeruginosa ilv $A 9\left(4 \times 10^{6}\right.$ organisms $\left./ \mathrm{ml}\right)$.

could be detected in the control experiments. Pseudomonas fluorescens Darrell acquired the property of gelatin liquefaction when treated with the DNA from P. aeruginosa 2 I5, with a frequency of $0.7 \%$. Neither the Darrell nor the ATCCI 2633 strain, however, was transformed for gelatin liquefaction from $P$. aeruginosa 78 . Fish Pseudomonas 21 , which is probably a strain of $P$. fluorescens, was transformed at a frequency of $0.8 \%$ when growth at $37{ }^{\circ} \mathrm{C}$ was used as a marker. This strain, however, did not acquire the property of gelatin liquefaction from $P$. aeruginosa LCI DNA.

The decay of transforming ability in the presence of DNase

The observation that the transforming ability of the DNA preparations was lost when treated with DNase suggests that transformation was DNA mediated. To examine this more closely, $P$. aeruginosa $i l v A 9$ and the prototrophic strain $P$. aeuruginosa 78 were chosen. Transforming DNA of the latter strain was treated with DNase for different periods to degrade the DNA to varying degrees, and the DNA preparations thus treated were applied to a competent culture of $P$. aeruginosa ilvA9 cells $\left(4 \times 10^{6}\right.$ organisms $\left./ \mathrm{ml}\right)$ and incubated for $10 \mathrm{~min}$ at $30{ }^{\circ} \mathrm{C}$. Frequency of transformation to prototrophy was then determined. The results (Fig. I) reveal that $50 \%$ of the activity was lost within $15 \mathrm{~s}$.

\section{DNA base composition}

The GC contents of the DNA of the strains used are given in Table 4. The range of GC contents of the strains is rather narrow, varying between $6 \mathrm{I} \cdot \mathrm{O}$ and $64.4 \mathrm{~mol} \%$. 
Table 4. Guanine + cytosine $(G C)$ contents of Pseudomonas strains

\begin{tabular}{|c|c|}
\hline Strain & $\begin{array}{c}\mathrm{GC} \\
\text { content } \\
(\mathrm{mol} \%)\end{array}$ \\
\hline$P$. aeruginosa LCI & $64 \cdot 0$ \\
\hline$P$. aeruginosa 215 & $63 \cdot 3$ \\
\hline P. aeruginosa 78 & $64 \cdot 4$ \\
\hline P. fluorescens ATCCI 2633 & $61 \cdot 0$ \\
\hline P. fluorescens Darrell & $62 \cdot 0$ \\
\hline P. fluorescens NRRL-BIO & $6 I \cdot 0$ \\
\hline Fish Pseudomonas I & $62 \cdot 4$ \\
\hline Fish Pseudomonas 2 I & $63 \cdot 3$ \\
\hline P. solanacearum $\mathrm{P} 25$ & $63 \cdot 3$ \\
\hline P. mangiferaeindicae $\mathbf{P} 24$ & 63.0 \\
\hline
\end{tabular}

Table 5. Effect of metal ions on the transformation frequency of Pseudomonas

Donor, Fish Pseudomonas I; recipient, P. fluorescens ATCCI2633; selected marker, gelatin liquefaction.

$\begin{array}{lccc}\text { Condition } & \begin{array}{c}\mathrm{IO}^{-4} \times \\ \text { trans- } \\ \text { formants/ } \\ \mathrm{ml}\end{array} & \begin{array}{c}\mathrm{IO}^{-6} \times \\ \text { viable } \\ \text { organisms/ } \\ \mathrm{ml}\end{array} & \begin{array}{c}\text { Trans- } \\ \text { formation } \\ \text { frequency } \\ (\%)\end{array} \\ \mathrm{No} \mathrm{salt} & 0 & 2 \cdot 4 & \mathrm{Nil} \\ \mathrm{BaCl}_{2}\left(\mathrm{IO}^{-3} \mathrm{M}\right) & 7 \cdot \mathrm{I} & 2 \cdot 3 & 3 \cdot \mathrm{I} \\ \mathrm{CaCl}_{2}\left(\mathrm{IO}^{-3} \mathrm{M}\right) & 5 \cdot 0 & \mathrm{I} \cdot 4 & 3 \cdot 5 \\ \mathrm{MgSO}_{4}\left(\mathrm{IO}^{-3} \mathrm{M}\right) & 9 \cdot 3 & 2 \cdot \mathrm{I} & 4 \cdot 4 \\ \mathrm{NaCl}\left(\mathrm{IO}^{-3} \mathrm{M}\right) & 0 \cdot 2 & \mathrm{I} \cdot 7 & 0 \cdot \mathrm{I} 2 \\ \mathrm{KCl}\left(\mathrm{IO}^{-3} \mathrm{M}\right) & 0 \cdot 5 & 2 \cdot 0 & 0 \cdot 25 \\ \mathrm{MnCl}_{2}\left(\mathrm{IO}^{-4} \mathrm{M}\right) & 0 & \mathrm{I} \cdot 7 & \mathrm{Nil} \\ \mathrm{FeSO}_{4}\left(\mathrm{IO}^{-4} \mathrm{M}\right) & 0 & \mathrm{I} \cdot 7 & \mathrm{Nil} \\ \mathrm{ZnSO}_{4}\left(\mathrm{IO}^{-4} \mathrm{M}\right) & 0 & \mathrm{I} \cdot 7 & \mathrm{Nil} \\ \mathrm{CuSO}_{4}\left(\mathrm{IO}^{-4} \mathrm{M}\right) & 0 & \mathrm{I} \cdot 7 & \mathrm{Nil}\end{array}$

Requirement of metal ions for transformation

It was observed that addition of $\mathrm{NaCl}$ or $\mathrm{KCl}$ results in transformation of only a small fraction of recipient cells (Table 5). But addition of such divalent metal ions as $\mathrm{Mg}^{2+}$, $\mathrm{Ca}^{2+}$ or $\mathrm{Ba}^{2+}$ markedly stimulated transformation and the frequency was enhanced several fold. Other divalent metal ions, which are usually included in culture media in relatively small quantities (e.g. $\mathrm{Fe}^{++}, \mathrm{Mn}^{++}, \mathrm{Zn}^{++}$and $\mathrm{Cu}^{++}$at a concentration of ${ }_{10}{ }^{-4} \mathrm{M}$ ), however, had no beneficial effect and not a single transformant was detected. Since sulphate ions do not appear to be useful for transformation, at least at a concentration of $\mathrm{IO}^{-4} \mathrm{M}$, the beneficial effect due to $\mathrm{MgSO}_{4}$ is probably due to magnesium ions.

\section{Requirement of DNA-dependent RNA synthesis during transformation}

Actinomycin D was found to reduce transformation. When $P$. fluorescens ATCCI 2633 was transformed with the DNA of Fish Pseudomonas I, the reduction was about $90 \%$. In the absence of actinomycin D, $4.6 \%$ of recipient cells were transformed to the property of gelatin liquefaction; after pretreatment with actinomycin D, only $0.46 \%$ were transformed. 


\section{DISCUSSIONS}

The investigations described here provide further evidence on the transformability of pseudomonads. One of the major factors controlling transformation is the degree of homology between the transforming and the recipient DNA. According to the recent hybridization studies of Palleroni, Ballard, Ralston \& Doudoroff (1972), P. aeruginosa and $P$. fluorescens belong to a single DNA homology complex. Apart from experimental conditions the homology of donor and recipient DNA determines the results of transformation experiments. The DNA base cornposition data of the strains used here suggest considerable genetic homology among the strains which have produced transformants. Five of the eleven combinations of $P$. fluorescens examined for transformation in the present and previous investigations have yielded positive results. But in spite of the close similarity in GC content of the strains used in the present investigation, only 2 out of 23 interspecific combinations produced transformants. The close GC contents of the two phytopathogens $P$. mangiferaeindicae $\mathrm{P} 24$ and $P$. solanacearum $\mathrm{P} 25$ are in good agreement with the results of interspecific experiments involving these two strains reported previously (Khan \& Sen, 1967); however, neither of these pathogens could transform or be transformed by the DNA of any other pseudomonad. The marker phenotype chosen is an important determinant of success in transformation experiments. Two of the three transformants obtained in the intraspecific transformation relate to gelatin liquefaction as a marker; in interspecific transformation the same character was transferred from $P$. aeruginosa DNA to $P$. fluorescens Darrell, but it could not be introduced from the DNA of any other strain of $P$. aeruginosa to any pseudomonad. To assess the taxonomic significance of the results of transformation experiments it is essential that several markers are employed.

Observations on the requirements for transformation in Pseudomonas provide some interesting information. In its metal ion requirements, $P$. fluorescens ATCCI2633 considerably resembled Bacillus subtilis (Young \& Spizizen, I963; Spizizen, Reilly \& Evans, I966) and B. licheniformis (Leonard, Matheis, Matheis \& Housewright, I964). Bivalent ions, particularly $\mathrm{Mg}^{2+}$, have been found to be highly beneficial for transformation. Transformation is known to depend on several metabolic processes and several inhibitors of respiration, nucleic acid and protein synthesis; for example, 2,4 dinitrophenol, mitomycin C, chloramphenicol and puromycin have been shown to inhibit transformation (Young Spizizen, 1961; Balassa, I963; Suzuki, Yamagami \& Shimazu, I965; Kammen, Wajner \& Canellakis, 1966). In the present investigation it has been observed that actinomycin $D$ at a concentration of $\mathrm{I} \rho \mu \mathrm{g} / \mathrm{ml}$ inhibits transformation by $90 \%$, indicating a requirement for DNA-dependent RNA synthesis.

\section{REFERENCES}

Balassa, G. (1963). Grenetic transformation of R.hizobium: A review of the work of R. Balassa. Bacteriological Review 27, 228-244.

Kammen, H. C., Wajner, R. J. \& Canellakis, E. S. (I966). Transformation in Bacillus subtilis. II. The development and maintenance of the competent state. Biochimica et biophysica acta 123, 56-65.

Khan, N. C. \& Sen, S. P. (1967). Genetic transformation in Pseudomonae. Journal of General Microbiology 49, $20 \mathrm{r}-209$.

Leonard, C. G., Matheis, D. K., Matheis, M. J. \& Housewright, R. D. (1964). Transformation to prototrophy and polyglutamic acid synthesis in Bacillus licheniformis. Journal of Bacteriology 88, $220-225$.

Marmur, J. \& Doty, P. (1962). Determination of the base composition of deoxyribonucleic acid from its thermal denaturation temperature. Journal of Molecular Biology 5, 109-1 18.

Morihara, K. (1964). Production of elastase and proteinase by Pseudomonas aeruginosa. Journal of Bacteriology 88, 745-757. 
Palleroni, N. J., Ballard, R. W., Ralston, E. \& Doudoroff, M. (I972). DNA homologies among some Pseudomonas species. Journal of Bacteriology rio, I-I I.

Spizizen, J., Reilly, B. E. \& Evans, A. H. (1966). Microbial transformation and transfection. Annual Review of Microbiology 22, 37I-400.

Suzuki, K., Yamagami, H. \& ShimazU, Y. (1965). Effect of mitomycin C on early phenotypic expression in the transformation of Diplococcos pneumoniae. Nature, London 205, 929-930.

Young, F. F. \& SpIzIZEN, J. (196r). Physiological and genetic factors affecting transformation of Bacillus subtilis. Journal of Bacteriology 81, 823-829.

Young, F. F. \& SpIzIzen, J. (1963). Incorporation of deoxyribonucleic acid in the Bacillus subtilis transformation system. Journal of Bacteriology 86, 392-400. 